\title{
Jonathan T. H. Wu Memorial Issue
}

\author{
Hoe I. Ling ${ }^{1}$
}

Published online: 3 August 2020

(C) Springer Science+Business Media, LLC, part of Springer Nature 2020

Dr. Jonathan T.H. Wu founded Transportation Infrastructure Geotechnology (TRIG), which was launched in January 2014. I had the great honor to work with him as co-editorin chief. I enjoyed the very best working relationship with Dr. Wu. We have established the annual Fumio Tatsuoka Best Paper Award associated with this journal. In 2016, TRIG was accepted for inclusion in Scopus, which is one of the main citation databases used for academic evaluation and promotion. With an increasing number of submissions and published papers every year, the journal is obviously in an upward trajectory.

On the morning of March 8, 2020, a beautiful Sunday in the midst of the coronavirus pandemic, I received a phone call from Ivan $\mathrm{Wu}$ who introduced himself as the son of Jonathan $\mathrm{Wu}$. I recognized the familiar voice and my immediate response was something might have gone wrong, else Ivan would not have called me. He brought the sad news informing me that his dad passed away on March 6 due to a heart attack. The tragedy was totally unexpected because $\mathrm{Dr}$. Wu was healthy and he was still very active in research. Just 2 months before this, he shared with me a few photos of Ivan's family, very proudly introducing me to his grandchildren.

How did I get to know Dr. Wu? Our connection dates back to 1989 when Dr. Wu took a sabbatical leave at the University of Tokyo, hosted by my advisor, Prof. Fumio Tatsuoka. In addition to passing his geotechnical knowledge to the students, Prof. Tatsuoka also brought his visitors/guests and students to become very close friends. I had an opportunity to work with Dr. Wu on the wide-width testing of geotextiles under soil confinements. During his first month in Tokyo, he stayed in my apartment, and thus, we had endless conversation days (on research) and nights (on various social issues). We commuted together on the subway. He later moved to the International House after his family arrived. But, he let his family carry for him a heavy PC because we did not have a universal DOS between Japan and US at that time. Thus, we had to take a cab from Narita International Airport to Roppongi, costing over 20,000 yen. Dr. $\mathrm{Wu}$ became good friends with every one of us in the lab. We all addressed him as Wu Sensei.

Hoe I. Ling

hil9@columbia.edu

1 Columbia University, New York City, NY, USA 
I have a few nice memories about Wu Sensei during his stay in Tokyo. In the lab, I noticed that he had been very interested in observing our testings using different kinds of equipment as well as the bearing capacity model tests. At that time, Prof. Dov Leshchinsky made his first trip to Japan. There was a Seminar at Seiken (Institute of Industrial Science), and we all had a very nice traditional dinner after that. On another occasion, Prof. Tatsuoka arranged for Wu Sensei to give a seminar at the Japanese Geotechnical Society, and I acted as his interpreter. Wu Sensei had also conducted research on pipe deflection; thus, he was keen on meeting with the late Prof. Masami Fukuoka, who has done field pipe testing. Prof. Fukuoka arranged for us to visit his lab at the Science University of Tokyo. Interestingly, we were also able to see his study on the leakage of geomembrane liners. I must also mention that Wu Sensei introduced to me the CANDE code, which I modified and used for reinforced soil structure analysis on a PC for many years.

In 1991, I made my first trip to the USA to attend the Geosynthetics Conference in Atlanta. I shared a room with Wu Sensei. He introduced me to gyros, which is still one of my favorite foods. I was able to meet a few of his students, including Nelson Chou (Nelson became a good friend, and he arranged for my visit to Taiwan after the 1999 Chi Chi earthquake). After the conference, I flew with them to Denver for a few days. I saw his lab and his preparation for the 1992 Prediction Symposium on the Denver Walls. I also saw the centrifuge facilities and true triaxial testing device at Boulder. Wu Sensei showed me around the very nice geological view. I revisited Denver in 1997 when $\mathrm{Wu}$ Sensei organized a symposium on mechanically stabilized backfill walls. What I would like to emphasize is that we kept in regular contact throughout the past three decades.

To honor his research achievements and contributions to TRIG, this Memorial Issue is dedicated to $\mathrm{Wu}$ Sensei. With the help of Christina Ma, I put down his research accomplishment with a list of major publications in the pages that follow.

Last but not least, I would like to express my sincere thanks to all the authors, coauthors, and friends who have contributed to this Memorial Issue. We truly missed Wu Sensei!

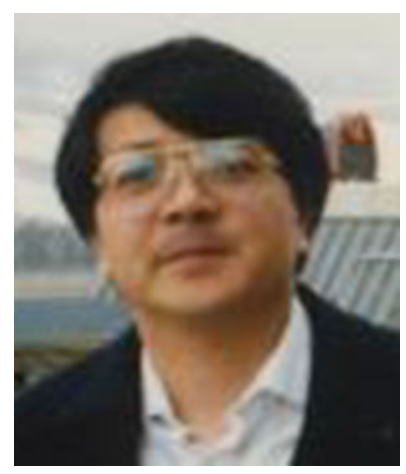

Wu Sensei (Denver, 1991) 


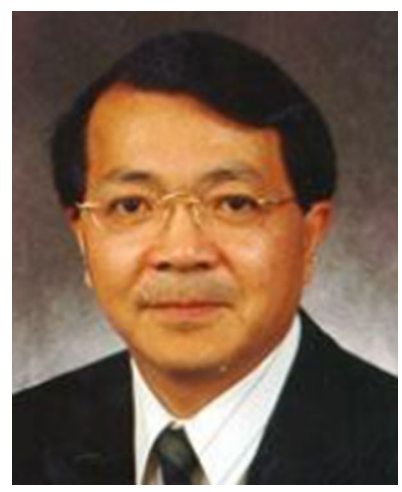

Professor Jonathan T.H. Wu.

(1951-2020)

Professor Jonathan T. H. Wu.

source: https://jonathanwu.weebly.com/

Dr. Jonathan T. H. Wu, Professor of Civil Engineering, University of Colorado Denver (CU Denver), Director of Reinforced Soil Research Center, and Editor-in-Chief of the Journal of Transportation Infrastructure Geotechnology, has been teaching and conducting research after earning his Ph.D. in Civil Engineering from Purdue University.

Dr. Wu's research interest is in the use of innovative physical and numerical modeling techniques to develop design methods and construction guidelines of sustainable earthwork systems, and to solve problems associated with earth structures. Since being awarded a Research Initiation Grant on "Pullout Failure Mechanism of Geosynthetic Reinforced Earth Structures" by the National Science Foundation at the beginning of his academic career, he has devoted a vast majority of his research effort in the development and applications of Geosynthetic Reinforced Soil (GRS) earthwork system. CU Denver is known by many as a leading research institute in reinforced soil, especially in the area of GRS. His research effort has made strong impacts and lead to many original contributions to the development and applications of GRS. It has been estimated that the GRS technology, when fully implemented, would save the nation over $\$ 1$ billion annually.

Professor $\mathrm{Wu}$ loves to challenge his students to become independent thinkers and be innovative. His homework problems have been known by many as "challenges of mind." In his own words: "Teaching adds great joy to my life and expands my mind. I especially enjoy teaching courses such as advanced soil engineering, groundwater and seepage, and design and construction of GRS, courses that are fundamental in nature or have heavy dosages of innovative applications...".

\section{Books and Book Chapters}

- $\quad$ GEOSYNTHETIC REINFORCED (GRS) WALLS, Wiley, 2017.

- MECHANICALlY STABILIZED BACKFILL, Editor, A. A. Balkema Publishers, Rotterdam, The Netherlands, 1997, 463 p. 
- DESIGN AND CONSTRUCTION OF LOW COST RETAINING WALLS THE NEXT GENERATION IN TECHNOLOGY, Colorado Transportation Institute and U. S. Forest Service, 1994, 152 p.

- "Reinforcement for Constructed Earth," (with W. V. Jones, L. R. Anderson, J. A. Bishop, and R. D. Holtz), Chapter 3, SOIL IMPROVEMENT - A TEN YEAR UPDATE, American Society of Civil Engineers, 1987, 331 p.

- TRANSPORTATION FACILITIES THROUGH DIFFICULTY TERRAIN, CoEditor (with R. K. Barrett), A. A. Balkema Publishers, The Netherlands, 1993, $611 \mathrm{p}$.

- GEOSYNTHETIC-REINFORCED SOIL RETAINING WALLS, Editor, A. A. Balkema Publishers, The Netherlands, 1992, 368 p.

- "Earthwork for Retaining Structures and Abutments," (with N. N. S. Chou and S. T. Yeh), Chapter 7, GUIDE TO EARTHWORK CONSTRUCTION - STATE OF THE ART REPORT, Transportation Research Board, National Research Council, 1990, $107 \mathrm{p}$.

- $\quad$ LATERAL LOAD CAPACITY OF CAISSONS AND PILES, Co-Editor (with N. N. S. Chou), Colorado Transportation Institute, November 1988, 340 p.

\section{Publications (since 1984)}

- Wu, J.T.H. and C.Y. Tung (2019). "Determination of Model Parameters for the Hardening Soil Model.” Transportation Infrastructure Geotechnology. Volume 6, doi:https://doi.org/10.1007/s40515-019-00085-8.

- Hoffman, P.F., Pham, T.Q., and Wu, J.T.H. (2019). Discussion: Xu, C., Liang, C., and Chen, P. (2019). "Experimental and Theoretical Studies on the Ultimate Bearing Capacity of Geogrid-Reinforced Sand," Geotextiles and Geomembranes.

- Wu, J.T.H. (2019). "Characteristics of Geosynthetic Reinforced Soil (GRS)Walls: An Overview of Field-Scale Experiments and Analytical Studies." doi.org/10.1007 /s40515-019-00074-X.

- Wu, J.T.H. (2018). “A Generic Design Protocol for Geosynthetic Reinforced Soil Foundation." Transportation Infrastructure Geotechnology. Volume 5, Issue 4, pp. 303-317. doi.org/10.1007/s40515-018-0061-2.

- Wu, J.T.H., Hoffman, P., and T.Q. Pham (2018). Discussion of "Numerical Simulation of Compaction-Induced Stress for the Analysis of GRS Walls under Working Conditions" by S. H. Mirmoradi and M. Ehrlich, Geotextiles and Geomembranes.46, pp. 913-914.

- Wu, J.T.H., Tung, C-Y, Adams, M.T., and Nicks, J.E. (2018). “Analysis of StressDeformation Behavior of Soil-Geosynthetic Composites in Plane Strain Condition." Transportation Infrastructure Geotechnology. Volume 5, Issue 3, pp. 210 230 .

- Helwany S., J.T.H. Wu, and R. Ghaderi (2017). "Seismic Behavior of Geosynthetic-Reinforced Soil Bridge Abutments-Experimental Study.” Transportation Infrastructure Geotechnology, Vol. 4, Issues 2-3, pp. 52-83.

- Helwany S., J.T.H. Wu, and R. Ghaderi (2017). "Seismic Behavior of Geosynthetic-Reinforced Soil Bridge Abutments-Analytical Study." Transportation Infrastructure Geotechnology, Vol. 4, Issue 4, pp. 85-105. 
- K.H. Yang, Wu, J.T.H., and Y.S. Chen (2016). "Numerical Study on Lateral Bearing Capacity and Failure Modes of Geosynthetic Reinforced Soil Barriers." Geotextiles and Geomembranes, Journal of International Geosynthetics Society, Volume 44, Issue 6, December 2016, pp. 799-812, DOI: https://doi.org/10.1016/j. geotexmem.2016.06.014

- Wu, J.T.H., Adams, M.T., and Nicks, N.E. (2016). Discussion of Xiao C. et al., "Experimental Study on Performance of Geosynthetic-Reinforced Soil Model Walls on Rigid Foundations subjected to Static Footing Loading," Geotextiles and Geomembranes, Vol. 44, Issue 1, February 2016, p. 81-94.

- Wu, J.T.H. and T.Q. Pham (2015). "Closure to "Load-Carrying Capacity and Required Reinforcement Strength of Closely Spaced Soil-Geosynthetic Composites." ASCE Journal of Geotechnical and Geoenvironmental Engineering, Vol. 141, No. 3, DOI: https://doi.org/10.1061/(ASCE)GT.1943-5606.0000885

- Yang, K.H., Wu, J.T.H., Chen, R.H., and Chen, Y.S. (2015). "Finite Element Study on Lateral Bearing Capacity and Failure Modes of GRS Barriers." (in Chinese) Proceedings, Fifth National GeoComposite Reinforced Soil Technology Conference.

- Wu, J.T.H. and Payeur, J.-B. (2015). “Connection Stability Analysis of Segmental Geosynthetic Reinforced Soil (GRS) Walls." Transportation Infrastructure Geotechnology. Volume 2, Issue 1, pp. 1-17, DOI: https://doi.org/10.1007 /s40515-014-0013-4

- Hoffman, P. and Wu, J.T.H. (2014). “An Analytical Model for Predicting LoadDeformation Behavior of the FHWA GRS-IBS Performance Test." International Journal of Geotechnical Engineering, Volume 9, No. 2, pp. 150-162, DOI: https://doi.org/10.1179/1939787914Y.0000000046

- Wu, J.T.H., Yang, K.-H., Mohammed, S., Pham, T.Q., and Chen, R.-H. (2014). "Suppression of Soil Dilation - A Reinforcing Mechanism of Soil-Geosynthetic Composites." Transportation Infrastructure Geotechnology. Volume 1, Issue 1, March, 2014, pp. 68-82, DOI:https://doi.org/10.1007/s40515-014-0003-6

- Nicks, J.E., Adams, M.T., Wu, J. (2013). “A New Approach to the Design of Closely Spaced Geosynthetic Reinforced Soil for Load Bearing Applications,” TRB Annual Compendium of Papers, Transportation Research Board, Washington, D.C.

- Flutcher, S. and Wu, J.T.H. (2013). "A State-of-the-Art Review of Geosynthetics in Low Volume Asphalt Roadway Pavements. ” International Journal of Geotechnical Engineering, Vol. 7, No. 4, pp. 411-422.

- Wu, J.T.H. and Pham, T.Q. (2013). "Load Carrying Capacity and Required Reinforcement Strength of Closely Spaced Soil-Geosynthetic Composites," Journal of Geotechnical and Geoenvironmental Engineering, ASCE, Vol. 139, No. 9. pp. 1468-1476.

- Wu, J.T.H., Adams, M.T., Pham, Q., Lee, S.H., and Ma, C. (2012) “A Generic Soil-Geosynthetic Composite Test." International Journal of Geotechnical Engineering, Vol. 6, Issue 1, pp. 103-116.

- Wu, J.T.H., Ma, C., Pham, Q., and Adams, M.T.(2011)“Required Minimum Reinforcement Stiffness and Strength in a Geosynthetic-Reinforced Soil (GRS) Wall," International Journal of Geotechnical Engineering, Vol. 5, Issue 4, pp. 403-412.

- Wu, J.T.H. and Pham. Q. (2010). “An Analytical Model for Calculating Lateral Movement of a Geosynthetic-Reinforced Soil (GRS) Wall with Modular Block Facing." International Journal of Geotechnical Engineering, Vol. 4, Issue 4,pp. 527-535. 
- Wu, J.T.H. and Pham. Q. (2010). "An Analytical Model for Evaluation of Compaction-Induced Stresses in Geosynthetic-Reinforced Soil (GRS) Mass." International Journal of Geotechnical Engineering, Vol. 4, Issue 4, pp. 549-556.

- Wu, J.T.H., Ketchart, K., and Adams, M.T. (2008). “Two Full-Scale Loading Experiments of Geosynthetic-Reinforced Soil (GRS) Abutment Wall.” International Journal of Geotechnical Engineering, Vol. 2, Issue 4, pp. 305-317.

- Wu, J.T.H. and Ketchart, K. (2008). "Investigating Failure of a GeosyntheticReinforced Soil Wall in Black Hawk, Colorado."6th International Conference on Case Histories in Geotechnical Engineering, Session 7a, Paper 7.11a.

- Helwany, S., Wu, J.T.H., and Kitsabunnarat, A. (2007). "Simulating the Behavior of GRS Bridge Abutments." Journal of Geotechnical and Geoenvironmental Engineering, American Society of Civil Engineers, Vol. 133, No. 10, pp. 1229-1240.

- Wu, J.T.H. (2007). "Lateral Earth Pressure against the Facing of Segmental GRS Walls." Geosynthetics in Reinforcement and Hydraulic Application, Geo-Denver 2007: New Peaks in Geotechnics, American Society of Civil Engineers, pp. 1-11.

- Wu, J.T.H. and Adams, M.T. (2007). "Myths and Facts on Long-Term Creep of GRS Structures." Geosynthetics in Reinforcement and Hydraulic Application, Geo-Denver 2007: New Peaks in Geotechnics, American Society of Civil Engineers, pp. 1-12.

- Adams, M.T., Ketchart., K., and Wu, J.T.H. (2007)."Mini Pier Experiments, Geosynthetic Spacing and Strength as Related to Performance." Geosynthetics in Reinforcement and Hydraulic Application, Geo-Denver 2007: New Peaks in Geotechnics, American Society of Civil Engineers, pp. 1-9.

- Wu, J.T.H., Lee, K., and Pham, T. (2006). "Allowable Bearing Pressure of Bridge Sills on GRS Abutments with Flexible Facing." Journal of Geotechnical and Geoenvironmental Engineering, American Society of Civil Engineers, Vol. 132, No. 7, pp. 830-841.

- Feng, Z. and Wu, J.T.H. (2006). "The Epsilon Method - Analysis of Seepage beneath an Impervious Dam with Sheet Pile on a Layered Soil." Canadian Geotechnical Journal, Vol. 43, No. 1, pp. 59-69.

- Lee, K. and Wu, J.T.H. (2004)."A Synthesis of Case Histories on GRS Bridge-Supporting Structures with Flexible Facing." Geotextiles and Geomembranes, Journal of the International Geosynthetics Society, Vol. 22, pp. 181-204.

- Ma, C. and Wu, J.T.H. (2004). "Performance of an Independent Full-Height Facing Reinforced Soil Wall." Journal of Performance of Constructed Facilities, American Society of Civil Engineers, Vol. 18, No. 3, pp. 165-172.

- Crouse, P. and Wu, J.T.H. (2003). "Geosynthetic-Reinforced Soil (GRS) Walls." Journal of Transportation Research Board, No. 1849, pp. 53-58.

- Helwany, S., Wu, J.T.H., and Froessl, B. (2003).“GRS Bridge Abutments - An Effective Means to Alleviate Bridge Approach Settlement." Geotextiles and Geomembranes, Journal of International Geosynthetics Society, Vol. 21, No. 3, pp. 177-196.

- Barrett B., Ruckman, A. and Wu, J.T.H. (2002). "Boundless Opportunity in Reinforced Soils for Those Who Will Accept Design and Construction Responsibility." Closing Lecture, Colorado ASCE Geotechnical Conference, Denver, Colorado.

- Ketchart, K. and Wu, J.T.H. (2002). "A Modified Soil-Geosynthetic Interactive Performance Test for Evaluating Deformation Behavior of GRS Structures.” ASTM 
Geotechnical Testing Journal, American Society of Testing and Materials, Vol. 25, No. 4, pp. 405-413.

- Adams, M.T., Lillis, C., Wu, J.T.H., and Ketchart, K. (2002).“Vegas GRS Mini Pier Experiment and the Postulate of Zero Volume Change." $7^{\text {th }}$ International Conference on Geosynthetics, Nice, France, pp. 389-394.

- Vessely, M. and Wu, J.T.H. (2002). "Feasibility of Geosynthetic Inclusion for Reducing Swelling of Expansive Soils." Transportation Research Record: Journal of the Transportation Research Board, Transportation Research Board of the National Academies, No. 1787, 2002, pp. 42-52.

- Wu, J.T.H. (2001). "Debunking the Myths on Design and Construction of Segmental GRS Walls." Special Lecture, International Geosynthetic Engineering Forum, Southeast Asia Section, International Geosynthetics Society, pp. 189-222.

- Ketchart, K. and Wu, J.T.H. (2001). "Wetting Induced Settlement of a Geosynthetic-Reinforced Soil Wall.” Annual Civil Engineering Conference, Thailand Society of Civil Engineers, pp. 42-61.

- Ketchart, K. and Wu, J.T.H. (2001). "Investigating Failure of a GeosyntheticReinforced Soil Wall." Soft Ground Improvement and Geosynthetics Applications, Symposium 2001, pp. 237-253.

- Wu, J.T.H. and Helwany, S. (2001). "Examining the Effects of Reinforcement in U.S. Forest Service Deep-Patch Landslide Repair Technique: Full-Scale Model Tests." Transportation Research Record: Journal of the Transportation Research Board, Transportation Research Board of the National Academies, No. 1772, pp. 203-210.

- Barrett, R., Ruckman, A., Wu, J.T.H., and Adams, M. (2000). "Reinforced Soil: A New Paradigm for Building Bridges." Keynote lecture, New Development in Reinforced Soil Retaining Structures, Taiwan, pp. 1-25.

- Adams, M.T., Ketchart, K., Ruckman, A., Dimillio, A., Wu, J.T.H., and Satyanarayana, R. (1999). "Reinforced Soil for Bridge Support Applications on Low-Volume Roads." Transportation Research Record: Journal of the Transportation Research Board, Transportation Research Board of the National Academies, No. 1652, pp.150-160.

- Helwany, S., Reardon, G., and Wu, J.T.H. (1999). "Effects of Backfill on the Performance of GRS Retaining Walls." Geotextiles and Geomembranes, Journal of International Geosynthetics Society, Vol. 17, No. 1, pp. 1-16.

- Ketchart, K. and Wu, J.T.H. (1997). "Performance of Geosynthetic-Reinforced Soil Bridge Pier and Abutment, Denver, Colorado, USA." Special Presentation, International Symposium on Mechanically Stabilized Backfill, A. A. Balkema Publishers, The Netherlands, 101-116.

- Ketchart, K., Wu, J.T.H., and Crouse, P. (1997). "How to Assess Long-Term Deformation of a GRS Structure?" International Symposium on Mechanically Stabilized Backfill, A. A. Balkema Publishers, The Netherlands, pp. 345-350.

- Wu., J.T.H. (1997). “An Overview and a Critique of Current Design Methods for GRS Structures.” International Symposium on Mechanically Stabilized Backfill, A. A. Balkema Publishers, The Netherlands, pp. 391-399.

- Wu, J.T.H. and Helwany, S. (1996). "A Performance Test for Assessment of Long-Term Creep Behavior of Soil-Geosynthetic Composites." Geosynthetic International, Journal of International Geosynthetics Society, Vol. 3, No. 1, pp. 107-124. 
- Wu, J.T.H. and Helwany, S. (1996). Closure to "A Numerical Model for Analyzing Long-Term Performance of Geosynthetic-Reinforced Soil Structures." Geosynthetic International, Journal of International Geosynthetics Society, Vol. 3, No. 4, pp. 557-559.

- Sobhi, S. and Wu, J.T.H. (1996). “An Interface Pullout Formula for Extensible Sheet Reinforcement." Geosynthetic International, Journal of International Geosynthetics Society, Vol. 3, No. 5, pp. 565-582.

- Wu, J.T.H. (1996). Discussion on "Earth Reinforcement: Testing and Materials." International Symposium on Earth Reinforcement Practice, A. A. Balkema Publishers, Kyushu, Japan.

- Monley, G. and Wu, J.T.H. (1995). Closure to "Tensile Reinforcement Effects on Bridge-Approach Settlement." Journal of Geotechnical Engineering, American Society of Civil Engineers, Vol. 121, No. 1, pp. 96-97.

- Helwany, S. and Wu, J.T.H. (1995). "A Numerical Model for Analyzing Long-Term Performance of Geosynthetic-Reinforced Soil Structures." Geosynthetics International, Journal of International Geosynthetics Society, Vol. 2, No. 2, pp. 429-453.

- Wu, J.T.H. and Helwany, S. (1994). "Use of Shredded Tires as Backfill for a New GRS Retaining Wall System." Fifth International Conference on Geotextiles, Geomembranes, and Related Products, Singapore, pp. 269-272.

- Yetimoglu, T., Wu, J.T.H., and Saglamer, A. (1994). "Bearing Capacity of Rectangular Footings on Geogrid-Reinforced Sand.” Journal of Geotechnical Engineering, American Society of Civil Engineers, Vol. 120, No.12, pp. 2083-2099.

- Chen, J.W., Lin, J.C., and Wu, J.T.H. (1994). "Engineering Behavior of Geosynthetic-Reinforced Soil Retaining Walls - A Parametric Study." Journal of National Cheng Kung University, Vol. 29, Science, Engineering and Medicine Division, pp. 139-153.

- Wu, J.T.H., Barrett, B., and Chou, N. (1994). "Developing Cost-Effective Geosynthetic-Reinforced Soil Walls: Recent Efforts in Colorado, U.S.A." Invited paper, Recent Case Histories of Permanent Geosynthetic-Reinforced Soil Retaining Walls, A. A. Balkema Publishers, The Netherlands, pp. 163180.

- Wu, J.T.H. (1994). Discussion on "Long-Term Clay-Geotextile Interaction." Recent Case Histories of Permanent Geosynthetic-Reinforced Soil Retaining Walls, A. A. Balkema Publishers, The Netherlands, pp. 343-344.

- Campbell, R. and Wu, J.T.H. (1994).“In-Plane Flow of Four Geosynthetics for Landfill Drainage." Geotechnical Testing Journal, American Society for Testing and Materials, Vol. 17, No. 1, pp. 3-16.

- Wu, J.T.H., Helwany, M., and Barrett, R. (1993). "Loading Test of MSB Wall - A New Geosynthetic-Reinforced Retaining Wall System." Soil Reinforcement: Full Scale Experiments of the 80's, Paris, pp. 583-603.

- Monley, G. and Wu, J.T.H. (1993). "Tensile Reinforcement Effects on BridgeApproach Settlement." Journal of Geotechnical Engineering, American Society of Civil Engineers, Vol. 119, No. 4, pp. 749-762.

- Chou, N. and Wu, J.T.H. (1993). "Effects of Foundations on the Performance of Geosynthetic-Reinforced Soil Walls." Geosynthetics '93 Conference, Industrial Fabrics Association International, Vancouver, British Columbia, Canada, Vol. 1, pp. 189-201. 
- Claybourn, A. and Wu, J.T.H. (1993). "Geosynthetic-Reinforced Soil Wall Design." Geotextiles and Geomembranes, Journal of International Geotextile Society, Vol. 12, No. 8, pp. 707-724.

- Wu, J.T.H. (1993). Discussion on "Deformation Measurement of Geotextiles by High Elongation Strain Gages." International Symposium on Earth Reinforcement Practice, Vol. 2, A. A. Balkema Publishers, The Netherlands, pp. 992-993.

- Wu, J.T.H. (1993). Discussion on "Limit Equilibrium Method versus Finite Element Method for Design of Geosynthetic-Reinforced Soil Structures." International Symposium on Earth Reinforcement Practice, Vol. 2, A. A. Balkema Publishers, The Netherlands, pp. 991-992.

- Wu, J.T.H. (1993). Discussion on "Measuring Inherent Confined Stiffness and Strength of Geotextiles." International Symposium on Earth Reinforcement Practice, Vol. 2, A. A. Balkema Publishers, The Netherlands, pp. 912-914.

- Wu, J.T.H. (1993). Discussion on "Finite Element Simulation of SoilReinforcement Interface Behavior.” International Symposium on Earth Reinforcement Practice, Vol. 2, A. A. Balkema Publishers, The Netherlands, pp. 991-992.

- Wu, J.T.H. (1993). "Design and Construction of Reinforced Wall Structures." Chairman's Report, Session 3, International Symposium on Earth Reinforcement Practice, Vol. 2, A. A. Balkema Publishers, The Netherlands, pp. 939-940.

- Ballegeer, J. and Wu, J.T.H. (1993). "Intrinsic Load-Deformation Properties of Geotextiles." Geosynthetic Soil Reinforcement Testing Procedures, ASTM STP 1190, American Society for Testing and Materials, pp. 16-31.

- $\quad$ Ling, H., Tatsuoka, F., Wu, J.T.H., and Nishimura, J. (1993). "Hydraulic Conductivity of Geotextiles under Typical Operational Conditions." Geotextiles and Geomembranes, Journal of International Geotextile Society, Vol. 12, No. 6, pp. 509-542.

- Chen, J.W., Wu, J.T.H., Claybourn, A.F. (1993). "Comparisons of Different Geosynthetic Reinforced Soil Walls.” Sino Geotechnics, No. 43, pp. 43-49.

- Wu, J.T.H., Siel, B., Chou, N., and Helwany, H. (1992). "The Effectiveness of Geosynthetic Reinforced Embankments Constructed over Weak Foundations." Geotextiles and Geomembranes, Journal of International Geotextile Society, Vol. 11, No. 2, pp. 133-150.

- Ling, H., Wu, J.T.H., and Tatsuoka, F. (1992). "Short-Term Strength and Deformation Characteristics of Geotextiles under Typical Operational Conditions." Geotextiles and Geomembranes, Journal of International Geotextile Society, Vol. 11, No. 2, pp. 185-219.

- Wu, J.T.H. (1992). "Predicting Performance of the Denver Walls: General Report." International Symposium on Geosynthetic-Reinforced Soil Retaining Walls, A. A. Balkema Publishers, The Netherlands, pp. 3-20.

- Wu, J.T.H. (1992). "Construction and Instrumentation of the Denver Walls." International Symposium on Geosynthetic-Reinforced Soil Retaining Walls, A. A. Balkema Publishers, The Netherlands, pp. 21-30.

- Wu, J.T.H. (1992). "Measured Behavior of the Denver Walls." International Symposium on Geosynthetic-Reinforced Soil Retaining Walls, A. A. Balkema Publishers, The Netherlands, pp. 31-41.

- Wu, J.T.H., Qi, X., Chou, N., Ksouri, I., Helwany, M., and Huang, C. (1992). "Comparisons of Predictions for the Denver Walls." International Symposium on 
Geosynthetic-Reinforced Soil Retaining Walls, A. A. Balkema Publishers, The Netherlands, March 1992, pp. 43-60.

- Claybourn, A. and Wu, J.T.H. (1992). "Failure Loads of the Denver Walls by Current Design Methods." International Symposium on Geosynthetic-Reinforced Soil Retaining Walls, A. A. Balkema Publishers, The Netherlands, pp. 61-77.

- Wu, J.T.H. and Tatsuoka, F. (1992). Discussion of "Laboratory Model Study on Geosynthetic Reinforced Soil Retaining Walls.” by I. Juran and B. Christopher, Journal of Geotechnical Engineering, American Society of Civil Engineers, Vol. 118, No. 3, pp. 496-498.

- Ling, H., Tatsuoka, F., and Wu, J.T.H. (1992). Discussion on "Effects of Back Pressure on Geotextile Transmissivity Tests." Geotechnical Testing Journal, American Society for Testing and Materials, Vol. 15, No. 3, pp.305-307.

- Helwany, B. and Wu, J.T.H. (1992). "A Generalized Creep Model for Geosynthetics." International Symposium on Earth Reinforcement Practice, Fukuoka, Kyushu, Japan, pp. 79-84.

- Billiard, J. and Wu, J.T.H. (1991). "Load Test of a Large-Scale GeotextileReinforced Retaining Wall." Geosynthetics '91 Conference, Industrial Fabrics Association International, Vol. 2, pp. 537-548.

- Claybourn, A. and Wu, J.T.H. (1991). "Case History Comparison of GeosyntheticReinforced Soil Walls.” Geosynthetics '91 Conference, Industrial Fabrics Association International, Vol. 2, pp. 549-560.

- Ling, H., Wu, J.T.H., and Tatsuoka, F. (1991). "Effectiveness of In-Membrane Test in Simulating Strength and Deformation Characteristics of a Nonwoven Geotextile under Operational Conditions." Geosynthetics '91 Conference, Industrial Fabrics Association International, Vol. 2, pp. 601-614.

- Wu, J.T.H. (1991). "Measuring Inherent Load-Extension Properties of Geotextiles for Design of Reinforced Structures." Geotechnical Testing Journal, American Society for Testing and Materials, pp. 157-165.

- Wu, J.T.H. (1991). "Predicting Performance of Geosynthetic-Reinforced Soil Retaining Walls - Bulletin 1.’Pre-Symposium, International Symposium on Geosynthetic-Reinforced Soil Retaining Walls, Denver, Colorado, pp. 164.

- Wu, J.T.H. (1991). "Predicting Performance of Geosynthetic-Reinforced Soil Retaining Walls - Bulletin 2.'Pre-Symposium, International Symposium on Geosynthetic-Reinforced Soil Retaining Walls, pp. 55-62.

- Wu, J.T.H. and Arabian, V. (1990). "Cubical and Cylindrical Tests for Measuring In-Soil Load-Extension Properties of Geotextiles.” Fourth International Conference on Geotextiles, Geomembranes and Related Products, The Hague, Vol. 2, pg. 785.

- Wu, J.T.H. and Helwany, H. (1990). "Alleviating Bridge Approach Settlement with Geosynthetic Reinforcement." Fourth International Conference on Geotextiles, Geomembranes and Related Products, The Hague, A. A. Balkema Publishers, Vol. 1, pp. 107-111.

- Ling, H., Tatsuoka, F. and Wu, J.T.H. (1990). "Strength and Deformation Characteristics of a Nonwoven Geotextile under Soil Confinement Conditions." 25th Japan National Conference on Soil Mechanics and Foundation Engineering, Okayama, Japan, pp. 2003-2006. 
- Ling, H., Tatsuoka, F., and Wu, J.T.H. (1990). "Measuring In-Plane Hydraulic Conductivity of Geotextiles," Geosynthetic Testing for Waste Contaminant Applications, ASTM STP 1081, American Society for Testing and Materials, pp. 257-272.

- Wu, J.T.H. (1989). "Behavior of Soil-Geotextile Composites and Its Application to Finite Element Analysis." Geosynthetics '89 Conference, Industrial Fabrics Association International, San Diego, California, Vol. 2, 365-372.

- Wu, J.T.H. and Monley, G. (1989). "Effectiveness of Tensile Reinforcement in Alleviating Bridge Approach Settlement." Geosynthetics '89 Conference, Industrial Fabrics Association International, San Diego, California, Vol. 1, pp. 104-111.

- Wu, J.T.H. and Tatsuoka, F. (1989). Discussion of "Laboratory Model Study on Geosynthetic Reinforced Soil Retaining Walls.” Journal of Geotechnical Engineering, American Society of Civil Engineers, pp. 905-926.

- Ling, H., Tatsuoka, F., and Wu, J.T.H. (1989). "The Permeability in Normal Direction of Geotextile under Confined Condition." Fourth Geotextile Symposium, Tokyo, Japan, pp. 63-67.

- $\quad$ Ling, H., Tatsuoka, F., and Wu, J.T.H. (1989). "In-Plane Hydraulic Conductivity of Geotextiles." Fourth Geotextile Symposium, Tokyo, Japan, pp. 56-62.

- Wu, J.T.H. (1989). "Load Test of a Geotextile-Reinforced Earth Wall Designed by the Forest Service Method." National Forum of Geosynthetics in Highway Applications, Denver, Colorado, pp. 47-67.

- Wu, J.T.H. (1989). "A Comparison of Design Methods of GeosyntheticReinforced Earth Walls." National Forum of Geosynthetics in Highway Applications, Denver, Colorado, pp. 68-94.

- Wu, J.T.H. (1989). “Geosynthetics Research at CU-Denver-1984-1989.”Keynote Lecture, National Forum of Geosynthetics in Highway Applications, Denver, Colorado, pp. 1-24.

- Wu, J.T.H. (1988). "Lateral Load Capacity of Caissons and Piles - A General Report." Symposium on Lateral Load Capacity of Caissons and Piles, Denver, Colorado, pp. 1-20.

- Wu, J.T.H. and Klumpp, C. (1988). "Ground Water Recharge for Retardation of Saltwater Intrusion - A Numerical Analysis.” Second International Symposium on Environmental Geotechnology, Shanghai, China, pp. 264-276.

- Wu, J.T.H. and Siel, B.(1988). "Investigating Performance of a GeogridReinforced Embankment over a Sanitary Landfill." Second International Symposium on Environmental Geotechnology, Shanghai, China, pp. 78-87.

- Siel, B., Wu, J.T.H., and Chou, N. (1987). "In-Soil Stress-Strain-Strength Characteristics of Geotextile." Geosynthetics '87 Conference, Industrial Fabrics Association International, New Orleans, Louisiana, Vol. 1, pp. 260-265.

- Wu, J.T.H. and Su, C. (1987). "Soil-Geotextile Interaction Mechanism in Pullout Test." Geosynthetics '87 Conference, Industrial Fabrics Association International, New Orleans, Louisiana, Vol. 1, pp. 250-259.

- Chou, N., Wu, J.T.H., and Siel, B. (1987). "The Effectiveness of Tensile Reinforcement in Strengthening an Embankment over Soft Foundation." Geosynthetics '87 Conference, Industrial Fabrics Association International, New Orleans, Louisiana, Vol. 1, pp. 332-340.

- Wu, J.T.H. and Chou, N. (1987). "Performance of Twin-Tee Retaining Wall for Interstate Highway 70 near Glenwood Canyon, Colorado." Prediction and 
Performance in Geotechnical Engineering, A.A. Balkema Publishers, The Netherlands, pp. 303-310.

- Wu, J.T.H. (1986). Discussion of "Coefficient of Soil Reaction for Buried Flexible Conduits." Journal of Geotechnical Engineering, American Society of Civil Engineers, Vol. 110, No. 7, pp. 1062-1065.

- Wu, J.T.H. and Beck, R. (1986). "Evaluation of the Modified Cam-Clay Model for Simulation of Soil Behavior under Different Stress Paths." Fifth International Conference on Mathematical Modeling, Berkeley, California.

- Leonards, G. and Wu, J.T.H. (1985). "Predicting Performance of Buried Metal Conduits." Transportation Research Record 1008, Journal of Transportation Research Board, National Research Council, pp. 42-52.

- Wu, J.T.H. (1985). Discussion on "Inelastic Buckling of Soil-Steel Structures." M. Ghobrial and G. Abdel-Sayed, Transportation Research Record 1008, Journal of Transportation Research Board, pp. 13-14.

- Wu, J.T.H. and Klumpp, C. (1985). "Numerical Simulation of Transit Contaminant Movement in Anisotropic Ground Water Aquifers." Modeling Environmental Flows, Vol. No. G00290, American Society of Mechanical Engineers, pp. 81-87.

- Wu, J.T.H. and Leonards, G. (1985). "Characterization of Soil Arching above Buried Pipes." International Conferences on Advances in Underground Pipeline Engineering, pp. 396-407.

- Wu, J.T.H., Chen, J., and Chou, N. (1985). Discussion on "Rational Charts for Method of Fragments Applied to Confined Seepage." by Griffiths, Geotechnique, Vol. 34, No. 2, pp. 375-377.

- Wu, J.T.H. and Beck, R. (1984). "Performance of Three Soil Models of a Clay." Fifth Engineering Mechanics Specialty Conference, American Society of Civil Engineers, pp. 1300-1303.

- Wu, J.T.H. and Klumpp, C. (1984). "Predicting Migration of Groundwater Contamination." Fifth Engineering Mechanics Specialty Conference, American Society of Civil Engineers, pp. 827-830.

- Chang, N. and Wu, J.T.H. (1984). "Stability of Large Spent Shale Embankments." Fifth Engineering Mechanics Specialty Conference, American Society of Civil Engineers, pp. 941-944.

- Wu, J.T.H. and Klumpp, C. (1984). "Sensitivity Analysis for Predicting Contaminant Movement in Groundwater Aquifers." Practical Applications of Groundwater Models Conference, American Water Well Association, pp. 478-497.

- Wu, J.T.H. and Klumpp, C. (1984). "Numerical Procedure for Simulating Migration of Groundwater Contamination." Practical Applications of Groundwater Models Conference, American Water Well Association, pp. 498-513.

Publisher's Note Springer Nature remains neutral with regard to jurisdictional claims in published maps and institutional affiliations. 